\title{
Books for Boys: Multicultural Literature with Strong Male Characters
}

\author{
Susan M. Landt \\ St. Norbert College \\ U. S. A.
}

\section{Boys need books with which they can connect, books that reach out to them with characters that reflect themselves, books that feature people who speak and look and act like the people in their lives. Among the functions of literature in children's lives, two are particularly relevant: facilitating literacy skills and providing role models. The path to becoming a proficient reader begins with the spark of interest in a book - the desire to know more. Young male readers need to envision characters like themselves in active roles: solving problems, undertaking responsibilities, exhibiting leadership, accomplishing worthy tasks.}

\author{
Literacy skills \\ Role Models \\ Making Selections \\ Locating Literature \\ Final Thoughts \\ Resources \\ Children's Literature Cited \\ References
}

"What about the boys?" asked an audience member at the conclusion of my presentation about multicultural literature. She explained that she came to the session hoping to learn about books with strong male role models from a diverse array of backgrounds. Her question caused me to reflect: I had shared a total of 32 selections covering a range of diversities; however, only nine of these books featured males. This was not the first time I heard from teachers about needing more multicultural resources for male students. I realized that I needed to refocus my effort if I was going to provide the information teachers required.

This paper seeks to do the following: introduce two significant purposes for including multicultural literature with male characters in the curriculum, describe how to locate and evaluate multicultural literature, and present a selection of picture books as examples of high-quality books with strong male characters.

Why is it important to furnish young males with literature that represents characters like themselves? Among the functions of literature in children's lives, two are particularly relevant: facilitating literacy skills and providing role models. 


\section{Literacy skills}

Boys continue to score lower than girls on standardized measures of reading achievement (Brozo, 2006; Watson, 2010). Moreover, according to the National Assessment of Educational Progress (NAEP), poor, Black, and Hispanic boys in the United States score significantly lower than their White male counterparts at all grade levels (Mead, 2006). As Zambo and Brozo point out: "Those who struggle most to learn how to read-who dominate remedial reading classes and programs, and who will suffer disproportionately as adults if they fail to become competent readers-are boys of color" $(2009$, p. 3$)$. While educators do not concur on the reasons for such disparities, there is no disagreement concerning the consequences of inadequate literacy skills. Brozo (2002) explains, "Skillful and critical reading ability is an important tool that boys must have to become academically successful...good readers are better students in every subject area" (p. 12).

While there are countless approaches toward helping students improve their reading skills, many agree that the more students read the more literacy levels increase (Zambo \& Brozo, 2009; Krashen, 1996; Whitehead, 2004). Krashen (1993) presents this argument:

When children read for pleasure, when they get "hooked on books," they acquire, involuntarily and without conscious effort, nearly all of the socalled "language skills" many people are so concerned about: They will become adequate readers, acquire a large vocabulary, develop the ability to understand and use complex grammatical instructions, develop a good writing style, and become good (but not necessarily perfect) spellers. Although free voluntary reading alone will not ensure attainment of the highest levels of literacy, it will at least ensure an acceptable level. (p. 84)

The path to becoming a proficient reader begins with the spark of interest in a book. The desire to know more about the characters, learn additional information about the topic, or discover how the plot ends, spurs novice readers into continuing their journey to increased literacy. If boys' literacy skills are to improve, they need to have literature that stimulates their interest and engages them in the process of reading. The need for engagement is reinforced by Kelley and Clausen-Grace (2009) whose study indicated that "highly engaged readers demonstrated higher levels of reading achievement than students who were less engaged" (p. 313). A motivating factor in students' interest in reading involves the ability of students to relate with the material. Hughes-Hassell, Barkley, and Koehler (2010) describe motivation as a key determinant of reading success: "Children tend to prefer and are more likely to engage with literature that reflects their personal experiences" (Role of Multicultural Literature section, para. 1). When children see themselves in books, they feel included and are more apt to be enticed into continuing the story. Zambo and Brozo (2009) refer to these books as "entry-point texts," stressing that boys who are able to engage with the characters are more likely to engage with the text. 
Conversely, Hefflin (2001) points out that "when readers do not encounter characters who are like them, reading is likely to be frustrating rather than pleasurable" ( $p$. 810). If appropriate reading material is not made available to young boys of color, if the images and characters they encounter never reflect their lives, or if only negative life experiences are presented, then they will have few opportunities to engage with the text and increase their literacy skills. Gangi (2008) notes, "White children whose experiences are depicted in books can make more text-to-self, text-to-text, and text-to-world connections than can children of color" (p. 30). Teachers need to consciously include literature that provides a range of engagement options for their students. Specifically, they must ensure that all students can find selections that reflect their families and their lives so that they have meaningful reading experiences. Including reading material that embraces students' cultural backgrounds leads to increased selfesteem and greater receptiveness to learning (Agosto, 2007).

\section{Role Models}

A second motive for integrating multicultural literature with strong male characters into the curriculum - the one sought by the teacher at the seminar involves providing role models for non-mainstream males. Boys need to encounter images to which they can relate; they need to see males like themselves demonstrating "values worth imitating and characters worth modeling" (Zambo \& Brozo, 2009, p. 9). Young male readers need to envision characters like themselves in active roles: solving problems, undertaking responsibilities, exhibiting leadership, accomplishing worthy tasks. Positive role models who look like themselves and have cultural experiences similar to their own help readers connect with the characters and the text and furnish "images of who they can become" (Zambo, 2007, p. 124).

All children need to see themselves in the literature they read or that is read to them. Wilfong (2007) describes the "excitement students feel when they find a text that reflects who they are. It is a mirror for their life, and it is validating" (p.1). Zambo and Brozo (2009) state that "the right kind of books-books with characters and themes that promote positive male values-will not only serve admirably as entry point material for boys, but will give them identity-affirming and even life-altering print experiences" (p. 7).

On the other hand, when boys from diverse backgrounds see only White males represented in the literature they read, what is the message they are receiving? "Not seeing self, or representations of one's culture, in literature can activate feelings of marginalization and cause students to question their place within society" (Landt 2005, p. 694). Sadker (2007) refers to the situation when groups are not included as "the null curriculum" and explains that students consequently lower their opinion about the groups not represented. When children's literature presents only White middle class characters as role models, students come to see this as "the norm" and view everyone else, potentially including themselves, as "other." Alternatively, literature offering a range of 
characters in active positive roles can "engender an appreciation for the diversity that occurs both within and across social groups...[and] can help students come to respect and value diversity as natural and enriching" (Bishop, 1997).

The images we set before our children influence their view of the world.... While picture books in general tell stories, introduce concepts, and provide information, multicultural picture books do it specifically and with attention to the details of diversity. . . . Through multicultural picture books, children are provided with either a mirror that reflects a cultural experience familiar to them or a window that offers a view of a cultural experience that is not their own. In both analogies, cultural experiences are validated and broadened for young people. (Gates, 2006)

When teachers acknowledge diverse cultures as essential components of curriculum, they reinforce a positive self-image for all students and emphasize the importance of every student's background.

\section{Making Selections}

Not every piece of literature featuring multicultural characters is an appropriate choice. There are a number of features that need to be considered when searching for literature to engage males from diverse backgrounds. Most importantly, the stories must be authentic and represent characters as real people, not portray them as different or foreign. Michael Dorris emphasizes this point in the foreword to Clambake: A Wampanoag Tradition.

This is a book about people who are neither exotic nor unusual. If you encountered them at a shopping mall or at a movie theater they might seem at first glance like anyone else, a grandfather proud of his grandson, American as apple pie. Clambake does not dispute this picture, but it does extend it. (Peters, 1992)

Other aspects to consider require careful reading of the text and examination of the illustrations. There are a number of guidelines available to assist in this task; the following questions were created by synthesizing criteria from a wide range of evaluation forms (Cai, 2002; Slapin, Seale, \& Gonzales, 1992; Shioshita, 1997). These questions are designed to help teachers make good choices when selecting literature featuring characters from diverse cultural perspectives.

- Are the characters part of society and not depicted as outsiders?

- Are the characters portrayed as individuals, not generic representations of the culture?

- Are the characters multi-dimensional and dynamic?

- Are the situations realistic and not perpetuating stereotypes? 
- Are problems and conflicts solved by individuals from the culture rather than by outsiders?

- Is the language spoken appropriate for the culture?

- Who tells the story, an outsider or an insider?

- What are the author's qualifications to write about this culture?

Even with guidelines, locating appropriate books with multicultural characters can be a daunting task for teachers with little time and minimal expertise in a diverse array of cultures.

\section{Locating literature}

The need for literature that appeals to young boys from diverse backgrounds is considerable; however, the resources are scarce and difficult to find. While more multicultural books are being published than in the past, selections are still inadequate. According to the Cooperative Children's Book Center (CCBC), out of the almost 35,000 children's books published from 2002 through 2008, about $7 \%$ were about people of color, with less than $4 \%$ of the total written by authors of color (2009). These statistics contrast with the changing data regarding school enrollment. In 2006 the U.S. Census Bureau reported that a little over $41 \%$ of students enrolled in school were of non-white background (2009).

The disparity between the need for multicultural selections and their availability is further compounded by teachers' lack of familiarity with the titles. The multicultural selections that are published are not generally well publicized nor prominently displayed in mainstream bookstores. Locating appropriate books to arouse the interest of a diverse population of students can be time consuming and frustrating. Teachers, with limited time to search out unfamiliar authors and titles, often have to rely on book lists, awards, and suggestions in textbooks.

Unfortunately, the book lists that teachers might look to for inspiration contain a paucity of multicultural choices. The Newbery and Caldecott book awards that teachers are most familiar with include few titles featuring diverse characters. The selections included in textbooks are equally inadequate, emphasizing primarily White middle-class characters (Gangi, 2008). Moreover, the most popular school-based book clubs, such as Scholastic Books, contain few multicultural selections. McNair (2008) reports that the Scholastic's preschool and K-1 order forms for the 2004-2005 academic year contained 600 selections by White authors and illustrators compared to 34 selections by authors and illustrators of color (p. 196).

Furthermore, according to a study done by Hughes-Hassell, Barkley, and Koehler (2010), Fountas and Pinnell Leveled Book List (2006), which teachers frequently use to determine appropriate books for students' reading levels, includes $83.5 \%$ of books at the transitional reading level, which contained one or 
more White main or secondary characters, while only $25.8 \%$ contained at least one character of color and only $2.2 \%$ were written by authors of color.

Lack of easily accessible resources constrains teachers' ability to provide adequate reading material for their students. Teachers cannot teach about what they do not know (Lowery \& Sabis-Burns, 2007). According to a study done by Smolen (2008), "Classroom teachers recognize the value of multicultural literature, but often need more information about this literature" (p. 18). If multicultural literature is to be a part of the curriculum, then teachers need to have knowledge of and access to an ample collection of such books from which to select.

Resources available to help teachers in their quest for choosing quality multicultural literature include book awards focusing on authors and illustrators from a specific perspective such as Latin American, Middle Eastern, Asian Pacific, and Native American (see resource section for awards and URLs). Most of the awards include books set in the United States as well as books featuring a global perspective. These awards provide excellent starting points for locating appropriate resources for classrooms. However, many of these awards were established in the middle 1990s and are not very well known outside of specific interest groups. A study conducted in 2010 revealed that less than $10 \%$ of teachers who responded were familiar with awards specific to cultural groups beyond the Coretta Scott King Award (Landt, 2011).

Other helpful sources include websites focusing on specific perspectives. A short list of highly recommended sites maintained by people with expertise in the specific cultural group is included in the resources section. Additional resources are publishers who concentrate on multicultural literature. A list comprised of a few reliable publishers of high quality books from diverse perspectives is also included in the resources section.

There are two concerns here: one of culture and one of gender. Both need to be addressed in order to provide young males from diverse backgrounds with richly motivating literacy experiences. Regrettably, there is an even greater scarcity of multicultural selections featuring males than there is of multicultural books featuring females (Anderson, 2005). With an already limited range of choices, the lack of strong male characters in the available books makes the quest for male-centered multicultural literature even more difficult for teachers already encumbered with a multiplicity of expectations. Therefore, the following selections are provided as exemplars. This is not an exhaustive list; however, there are many other fine choices available for teachers to consider. Additional books can be located by looking up the author and/or illustrator and by checking the websites and publishers provided in the list of resources.

These recommendations comprise picture books because they provide visual depictions of cultural diversity. The books chosen are currently in publication with reading and interest levels ranging from pre-school through eighth grade. All of the books are set within the United States. Each selection has male main characters from a non-Anglo-European background and a story line demonstrating positive characteristics such as courage, patience, 
determination, and cooperation. Cultural authenticity has been ascertained through application of evaluation guidelines including author and illustrator credentials regarding expertise with the specific culture.

Selections were located through a number of means including awards specific to cultural groups, websites created and maintained by individuals knowledgeable about a culture, publishers focusing on multicultural books, recommendations from people with expertise in a culture, and dogged searching for information leading to discovery of quality books appropriate for use in classrooms.

\section{Books Appropriate for Pre-Kindergarten through Second Grade}

The first set of selections consists of picture books that are excellent choices for the youngest students. Although each book can also be used with older students, these books feature relationships that will be familiar to most young students: friendships, family, and classmates. The stories told and characters portrayed provide harmonious pictures of young children's encounters with events common within their age group.

Cleversticks by Bernard Ashley (2002) features a young boy and his first experiences with school. After the first day of school, Ling Sung decides he does not want to go back because he thinks the other children have special talents and he does not. Without intending to, Ling Sung demonstrates his ability to use chopsticks. All of the other children are fascinated and beg him to teach them. Ling Sung learns that everyone is special in different ways.

My Pal, Victor/Mi Amigo, Victor by Diane Gonzales Bertrand (2004) is an amazing find. Written in both English and Spanish, this book features two young Latino boys and the many activities they do together. On each page the young protagonist tells about how his friend Victor makes all of their activities extra special from telling stories and jokes to swimming and riding roller coasters. It is not until the final page that we see Victor in a wheelchair.

Pablo's Tree by Pat Mora (1994) tells the tale of a young boy and the special bond he has with his Abuelito (grandfather). Each year Pablo's Abuelito decorates the tree he planted to celebrate the day he was adopted. Pablo's Tree provides a simple story about the relationship with a grandparent with which many young boys will be able to relate.

Papa and Me by Arthur Dorros (2008) portrays a father and son experiencing an ordinary day of activities from an early morning breakfast of pancakes to the setting of the sun. The father speaks Spanish while the son communicates in both Spanish and English-a situation which many children experience.

She Come Bringing Me that Little Baby Girl by Eloise Greenfield (1993) presents a scenario that is likely to be familiar to young boys. Kevin was excited about the prospect of having a baby brother. When his mother comes home with a baby girl, Kevin is disappointed and refuses to have anything to do with her. 
Slowly, he is encouraged by his family to take on the role of big brother so he can teach her all the things he knows.

\section{Books for Thinking: Third through Fifth Grade}

The next set of books contains plots that are slightly more complex. While they are still appropriate for the youngest students, they also offer scenarios that can stimulate discussion with somewhat older children. Relationships play an important part in each of the stories; there are also deeper elements present as characters encounter situations requiring them to demonstrate positive characteristics. Each story illustrates an important value such as generosity, persistence, loyalty, and respect.

Sam and the Lucky Money by Karen Chinn (1995) focuses on a dilemma confronting Sam: how to spend the lucky money he received in celebration of New Year's Day. His trip through Chinatown with his mother presents choices and disappointment as he encounters a lesson in economics. Sam's decision demonstrates a young boy's ability to see beyond himself.

By My Brother's Side by Tiki and Ronde Barber (2004) is a special treat for boys who are interested in football. Told by the NFL-playing brothers, they relate the time Tiki broke his leg and the boys (identical twins) were forced to be apart. The story presents a strong image of family ties and perseverance reinforced by the fact that it is biographical.

Willie Wins by Almira Astudillo Gilles (2001) relates how a coconut shell bank, a baseball card, and a school bully are central to Willie's awakening appreciation for his Philippine heritage. A loving father-son relationship and a young boy's belief in his father provide strong positive images of solid family relationships.

Family, Familia by Diane Gonzales Bertrand (1999) describes how Daniel, a young boy from Kingston, comes to appreciate the meaning of family during a reunion of all the descendents of his great great grandparents. Originally reluctant to attend the reunion - thinking he would have nothing to do - Daniel discovers connections that flow through generations and begins to appreciate the importance of belonging to the greater vision of family.

Jalapeño Bagels by Natasha Wing (1996) presents an increasingly common dilemma for children whose backgrounds span multiple cultures. International Day at school sends Pablo into a quandary as he struggles to fulfill the assignment to bring something from his culture to school. While working with his parents at their bakery, Pablo tests different ideas, but each represents only half of his heritage: either Mexican or Jewish. Pablo finds a solution in Jalapeño bagels, a blend of both his cultures, just like him! 


\section{Problem Solving: Fourth through Eighth Grade}

The picture book genre consists of more than books intended for young children. While some of them can easily be enjoyed by the youngest listeners and readers, others require a bit more sophistication to garner full appreciation of the content. The following selections contain situations where young male protagonists contend with challenges which induce mature decision making to resolve problems. These books, while still appropriate for second and third grade students, will be more fully appreciated by students in fourth through eighth grade.

My Name is Bilal by Asama Mobin-Uddin (2005) focuses on how Bilal contends with the discrimination he and his sister, Ayesha, face when they move to a school with few other Muslim students. Bilal at first tries to deny that he is Muslim until Mr. Ali, his teacher, helps him see the importance of being proud of who he is.

Grandfather's Story Cloth by Linda Gerdner and Sarah Langford (2008) also exemplifies the importance of family and connections to the past. Chersheng is a young boy coping with the gradual decline of his beloved grandfather's memory. When his mother shares the story cloth his grandfather made depicting his life in Laos, Chersheng gets the idea to create a story cloth for grandfather illustrating his life since coming to America.

Saltypie: A Choctaw Journey from Darkness into Light by Tim Tingle (2010) is a complex account of a young boy's family history focused on the story of his grandmother and the challenges she faced as the family moved from Oklahoma Choctaw country to Pasadena, TX.

Oh, Brother by Nikki Grimes (2008) presents a family situation where two young boys struggle with their new roles in a recently blended family. Xavier worries that his new step-brother is taking over his mother's attention, while Chris is afraid that if he is not perfect his dad might go away the way his mom did. The boys finally begin to understand one another's feelings as each takes on the role of brother.

Behind the Mask by Yangsook Choi (2006) begins as Kimin considers what he wants to be for Halloween. Kimin discovers the scary mask his late grandfather wore as a dancer in Korea and decides to use it for his costume without telling his mother. After the mask is damaged, Kimin fears his mother's reaction, but a note from his grandfather helps resolve the situation as Kimin understands the love his grandfather held for him.

\section{Real People as Role Models}

The following selections provide a range of examples of historical figures who serve as role models for young male readers. Each exhibits characteristics 
that contributed to success despite challenging obstacles. The stories are engaging while also illustrating such positive characteristics as courage, persistence, cooperation, diligence, generosity, and wisdom.

Jim Thorpe's Bright Path by Joseph Bruchac (2004) is an amazing account of the life of Jim Thorpe from his earliest days, his experiences in Agency Boarding schools, the tragic loss of his twin brother, and his determination to excel and help his people. His story stands as one of the greatest examples of perseverance, talent, and resolve. Dominating whatever game he played - football, track, baseball -- Jim Thorpe is a role model for Native American youth as well as an example for all people to emulate.

Jose! Born to Dance: The Story of Jose Limon by Susanna Reich (2005) illustrates how Jose, a young Mexican boy, succeeded in the world of American dance during the 1900s. The rich images and lyrical text paint a picture of Jose's talent and his untiring determination to succeed as a dancer and choreographer in the United States.

Piano Starts Here: The young Art Tatum by Robert Andrew Parker (2008) imagines the early life of the great Jazz player Art Tatum. Born with poor eyesight that never improved, Art learned how to play the piano in his earliest years, astonishing family and neighbors. His story relates how he was able to overcome the limitations of his vision with persistence and determination.

Roberto Clemente: Pride of the Pittsburg Pirates by Jonah Winter (2005) illustrates how determination and perseverance made Puerto Rican Roberto Clemente one of the greatest baseball players of all time. More importantly, this short biography provides a picture of a person whose greatness extended far beyond baseball as he reached out to help others.

Sixteen Years in Sixteen Seconds: The Sammy Lee Story by Paula Yoo and Dom Lee (2005) describes Sammy Lee's journey to become an Olympic champion despite the immense difficulties he faced due to discrimination. Barred from swimming in the public pool, which was reserved for Whites every day except Wednesday, Sammy practiced diving into a sandpit in his coaches' backyard. Encountering prejudice and discrimination throughout his life, Sammy persisted in his goal to become a doctor and to make the Olympic diving team. Winning a gold medal in the 1948 Olympics, he achieved his objective, demonstrating to the world that people should not be judged by the color of their skin.

\section{Final Thoughts about Using Multicultural Literature in the Classroom}

Literature featuring strong male role models from a diverse array of cultures ought to be a part of every elementary teacher's curriculum. These books should not be used as unconnected pieces of literature brought out for special holidays or times designated as featuring a specific cultural group. Multicultural literature needs to be integrated within the regular curriculum on a consistent basis. Multicultural texts make excellent choices for a multitude of 
teaching activities including selecting books to read aloud to the class, or choosing literature for a lesson on writing.

Individual books lend themselves to a variety of lessons. For example, Cleversticks is a great resource for introducing the topic of differences as young students begin to think about how all their classmates have different abilities. Sam and the Lucky Money can help students learn about plot. Oh, Brother is perfect for having students work on perspective because they can look at the situation from the point of view of all four characters involved in the story. Willie Wins and Family/Familia both provide opportunities for teaching about characterization. The stories about Jim Thorpe and Sammy Lee make excellent reading when studying the Olympics. Jim Thorpe's Bright Path can also serve as an introduction to the history of how young Native American children were sent to boarding schools and forbidden to speak their native language. These few ideas are merely a beginning. Once teachers begin to consider this literature as a powerful teaching resource, a myriad of ways will be found to enrich the curriculum with a diversity of selections. By consistently including multicultural selections with strong male characters, teachers will be demonstrating the importance of all cultures while also stimulating the interest of young boys who see themselves in the selections.

\section{Resources}

Below are a few select resources to assist in locating multicultural children's literature. These sites are all current and contain examples and helpful information regarding selections featuring a range of diverse perspectives. For the most part, these awards concentrate on books set in the United States. The Middle East Book Award focuses on books contributing to an understanding of the Middle East.

The other websites contain a combination of recommendations for books set in the United States as well as a variety of countries appropriate to the focus of the site. All sites were last accessed October 10, 2012.

\section{Awards}

Americas Award http://www4.uwm.edu/clacs/aa/index.cfm

Asian Pacific American Librarians Association Award

http://www.apalaweb.org/awards/literature-awards/

Chinese American Association Best Book of the Year http://www.calaweb.org/node/879

Coretta Scott King Award

http://www.ala.org/ala/mgrps/rts/emiert/cskbookawards/index.cfm

John Steptoe Award for New Talent

http://www.ala.org/template.cfm?template=/CFApps/awards_info/award_detail_h 
ome.cfm\&FilePublishTitle=Awards,\%20Grants\%20and\%20Scholarships\&uid=39 BDDA5E6AB38D36

Middle East Book Award http://www.meoc.us/

Native American Youth Services Literature Award

http://ailanet.org/activities/american-indian-youth-literature-award/

Pura Belpre Award

http://www.ala.org/ala/mgrps/divs/alsc/awardsgrants/bookmedia/belpremedal/bel preabout/index.cfm

Tomas Rivera Mexican American Children's Award

http://www.education.txstate.edu/c-p/Tomas-Rivera-Book-Award-Project-

Link.html

\section{Websites}

American Indians in Children's Literature

http://americanindiansinchildrensliterature.blogspot.com/

The Brown Bookshelf http://thebrownbookshelf.com/

Celebrating Cultural Diversity through Children's Literature

http://www.multiculturalchildrenslit.com/

Children's and YA Author Cynthia Leitich Smith

http://www.cynthialeitichsmith.com/index.html

Mitali's Fire Escape http://www.mitaliperkins.com/

Paper Tigers http://www.papertigers.org/

\section{Publishers Featuring Multicultural Literature}

Arte Público Press http://www.latinoteca.com/arte-publico-press

Black Books Galore! http://www.blackbooksgalore.com/index.html

Lee \& Low Books http://www.leeandlow.com/

Raven Tree Press http://www.deltapublishing.com/index2.cfm

Shen's Books http://www.shens.com/

Tilbury House http://www.tilburyhouse.com/books-childrens.htm

\section{Children's Literature Cited}

Ashley, B. (2002). Cleversticks (D. Brazell, Illustrator). New York: Harper Collins Children's Books. 
Barber T., \& Barber, R. (2004). By my brother's side (B. Root, Illustrator). New York, NY: Simon \& Schuster/Paula Wiseman Books.

Bertrand, D. G. (1999). Family, familia (P. G. Howard, Illustrator). Houston, TX: Piñata Books.

Bertrand, D. G. (2004). My pal, Victor/mi amigo, Victor (R. L. Sweetland, Illustrator). McHenry, IL: Raven Tree Press.

Bruchac, J. (2004). Jim Thorpe's bright path (S. D. Nelson, Illustrator). New York, NY: Lee \& Low Books Inc.

Chinn, K. (1995). Sam and the lucky money (C. Van Wright \& Y. Hu, Illustrators). New York, NY: Lee \& Low Books Inc.

Choi, Y. (2006). Behind the mask. New York, NY: Frances Foster Books.

Dorros, A. (2008). Papa and me (R. Gutierrez, Illustrator) New York, NY: Rayo.

Gerdner, L., \& Langford, S. (2008). Grandfather's story cloth (S. Loughridge, Illustrator). Walnut Creek, CA: Shen's Books.

Gilles, A. A. (2001) Willie wins (C. Angel, Illustrator). New York, NY: Lee \& Low Books.

Greenfield, E. (1993) She come bringing me that little baby girl (J. Steptoe, Illustrator). New York, NY: HarperCollins.

Grimes, N. (2008). Oh, brother! (M. Benny, Illustrator). New York, NY: Greenwillow Books.

Mobin-Uddin, A. (2005). My name is Bilal (B. Kiwak, Illustrator). Honesdale, PA: Boyds Mill Press.

Mora, P. (1994). Pablo's tree. (C. Lang, Illustrator). New York, NY: Harcourt Brace \& Company.

Parker, R. A. (2008). Piano starts here: The young Art Tatum. New York, NY: Schwartz Wade Books.

Reich, S. (2005). Jose! born to dance: The story of Jose Limon (R. Colon, Illustrator). New York, NY: Simon \& Schuster/Paula Wiseman Books.

Tingle, T. (2010) Saltypie: A Choctaw journey from darkness into Light (K. Clarkson, Illustrator). El Paso, TX: Cinco Puntos Press.

Wing, N. (1996).Jalapeño bagels (R. Casilla, Illustrator). New York, NY: Atheneum Books for Young Readers.

Winter, J. (2005). Roberto Clemente: Pride of the Pittsburgh Pirates. (R. Colon, Illustrator). New York, NY: Antheum Books for Young Readers.

Yoo, P. (2005). Sixteen years in sixteen seconds: The Sammy Lee story. (D. Lee, Illustrator). New York, NY: Lee \& Low. 


\section{References}

Agosto, D. (2007). Building a multicultural school library: Issues and challenges. Teacher Librarian , 34(3), 27-31.

Anderson, D. A. (2005). Gender role stereotyping of parents in children's picture books: The invisible father. Sex Roles, 52(3/4), 154-151.

Bishop, R. (1997). Selecting literature for a multicultural curriculum. In V. J. Harris, Using multiethnic literature in the K-8 classroom (pp. 1-20). Norwood, MA: Christopher-Gordon Publishers, Inc.

Brozo, W. G. (2002). To be a Boy, to be a Reader. Newark,DE: International Reading Association.

Brozo, W. G. (2006). Bridges to literacy for boys. Educational Leadership, 64(1), 71-74.

Cai, M. (2002). Multicultural literature for children and young adults: Reflections on critical issues. Westport, CT: Greenwood Press.

Cooperative Children's Book Center. (2009). Children's books by and about people of color published in the United States. Retrieved from http://www.education.wisc.edu/ccbc/books/pcstats.asp

Fountas, I., \& Pinnell, G. (2006). Leveled books (k-8): Matching texts to readers for effective teaching. Portsmouth, $\mathrm{NH}$ : Heinemann.

Gangi, J. M. (2008). The unbearable whiteness of literacy instruction: Realizing the implications of the proficient reader research. Multicultural Review, 17(1), 30-38.

Gates, P. S., \& Mark, D. L. (2006). Cultural Journeys: Multicultural literature for children and young adults. Lanham, MD: The Scarcrow Press.

Hefflin, B. R., \& Barksdale-Ladd, M. A. (2001). African American children's literature that helps students find themselves: Selection guidelines for grades K-3. The Reading Teacher, 54(8), 810-819.

Hughes-Hassell, S., Barkley, H., \& Koehler, E. (2010, February 24). Promoting equity in children's literacy instruction: Using a critical race theory framework to examine transitional books. Retrieved from http://www.ala.org/ala/mgrps/divs/aasl/aas/pubsandjournals/slmrb/slmrcon tents/volume12/hughes hassell.cfm

Kelley, M. J., \& Clausen-Grace, N. (2009). Facilitating engagement by differentiating independent reading. The Reading Teacher, 63(4), 313318.

Krashen, S. (1993). The Power of Reading: Insights from the research. Englewood, CO: Libraries Unlimited.

Krashen, S. (1996). Every person a reader: An alternative to the California task force report on reading. Culver City, CA: language Education Associates. 
Landt, S. (2005). Multicultural literature and young adolescents: A kaleidoscope of opportunity. Journal of Adolescent and Adult Literacy, 49(8), 690-698.

Landt, S. (2011). Integration of multicultural literature in primary grade Language Arts curriculum. The Journal of Multiculturalism in Education, $7(1)$. Retrieved from http://www.wtamu.edu/journal/volume-7-number-2.aspx\#9

Lowery, R. M., \& Sabis-Burns, D. (2007). From Borders to Bridges: Making cross-cultural connections through multicultural literature. Multicultural Education, 14(4), 50-54.

McNair, J. (2008). The Representation of authors and illustrators of color in school-based book clubs. Language Arts, 85(3), 193-201.

Mead, S. (2006). The Truth about boys and girls. Retrieved from http://www.doxtop.com/browse/7ab824c6/the-truth-about-boys-andgirls.aspx

Peters, R. M. (1992). Clambake A wampanoag Tradition. New York, NY: Lerner Publishing Group.

Sadker, D., \& Zittleman, K. (2007). Gender bias: From colonial America to today's classrooms. In J. A. Banks \& J. A. Banks (Ed.), Multicultural education: Issues and perspectives (pp. 135-169). Hoboken, NJ : Wiley.

Shioshita, J. (1997, September-October). Beyond good intentions: Selecting multicultural literature. Retrieved from http://www.4children.org/issues/ 1997/september october/beyond good intentions selecting multicultural literature/

Slapin, B., Seale, D., \& Gonzales, R. (1992). How to tell the difference: A checklist. In B. S. Slapin, The Native expereince in books for children. Philadelphia, PA: New Society Publishers.

Smolen, L. A. (2008). Enhancing cultural understanding and respect with multicultural text sets in the K-8 classroom. Ohio Journal of English Language Arts, 48(2), 18-29.

U.S. Census Bureau. (2009, October 2). School enrollment. Retrieved from http://www.census.gov/population/www/socdemo/school.html

Watson, A., Kahler, M., \& Martino, W. (2010). The problem of boy's literacy underachievemnt: Raising some questions. Journal of Adolescent \& Adult Literacy, 53(5), 356-361.

Whitehead, N. (2004). The effects of increased access to books on student reading using the public library. Reading Improvement, 41(3), 165-178.

Wilfong, L. G. (2007). A mirror, a window: Assisting teachers in selecting appropriate multicultural young adult literature. International Journal of Multicultural Education, 9(1), 1-13. 
Zambo, D. (2007). Using picture books to provide archetypes to young boys: Extending the ideas of William Brozo. The Reading Teacher, 6(12), 124131.

Zambo, D., \& Brozo, W. G. (2009). Bright beginnings for boys: Engaging young boys in active literacy. Newark, DE: International Reading Association. 